\title{
Health Care Professionals' Views on Healthcare Provision During the COVID-19 Pandemic: A Descriptive Study
}

\section{Sağlık Çalışanlarının COViD-19 Salgını Sırasında Sağlık Hizmeti Sunumuna ilişkin Görüşleri: Betimleyici Bir Çalışma}

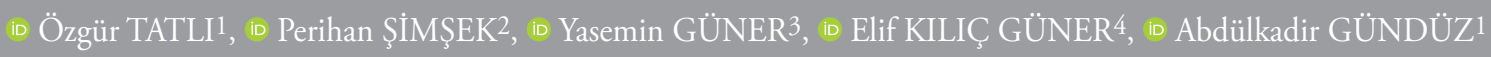 \\ 'Karadeniz Technical University Faculty of Medicine, Department of Emergency Medicine, Trabzon, Turkey \\ ${ }^{2}$ Balıkesir University Faculty of Health Sciences, Balıkesir, Turkey \\ ${ }^{3}$ Karadeniz Technical University, Faculty of Medical Science, Department of Medical Education, Trabzon, Turkey \\ ${ }_{4}^{4}$ Karadeniz Technical University Faculty of Health Sciences, Education Coordinator, Trabzon, Turkey
}

\begin{abstract}
Objective: The Coronavirus disease-19 (COVID-19) pandemic outbreak put a heavy burden on the health system. In this process, determining the difficulties faced by healthcare professionals is important in terms of making the necessary preparations for similar outbreaks and improving healthcare provision. The aim of the study was to determine the views of healthcare professionals about healthcare provision and the difficulties they faced during the COVID-19 pandemic period.
\end{abstract}

Methods: The descriptive study was carried out with the participation of 89 doctors and 58 nurses working in a university hospital in the Black Sea Region. In the study, the data form developed by the researchers and the job-related strain were used as data collection tools.

Results: While the psychological difficulty stated by the participants in the study was the anxiety of infecting the family/relatives (93.2\%), the factor that made the service delivery the most participants was expressed as the discomfort $(85 \%)$ caused by using personal protective equipment. It was found that the level of anxiety felt while providing healthcare services was higher in women compared to men $(\mathrm{p}=0.01)$ and nurses than physicians $(\mathrm{p}=0.001)$. The average score of the participants on the job-related strain was 37.51 \pm 5.80 .

Conclusion: The concern of infecting relatives/family during the COVID-19 pandemic poses a psychological difficulty for healthcare

\section{ÖZ}

Amaç: Koronavirüs Hastalı̆̆ı-19 (COVID-19) pandemisi sağlık sistemi için ağır bir yük getirmiştir. Bu süreçte, sağlık çalışanlarının karşılaştığı güçlüklerin belirlenmesi, benzer salgınlar için gerekli hazırlıkların yapılabilmesi ve sağlık hizmeti sunumunun iyileştirilebilmesi açısından önem taşımaktadır. Çalışmada sağlık çalışanlarının COVID-19 salgın döneminde sağlık hizmeti sunumuna ilişkin görüşlerinin ve bu süreçte karşılaştıkları güçlüklerin belirlenmesi amaçlandı.

Yöntemler: Tanımlayıcı nitelikte olan çalışma Karadeniz Bölgesi'nde bulunan bir üniversite hastanesinde çalışmakta olan 89 doktor ve 58 hemşirelerin katılımıyla gerçekleştirildi. Çalışmada veri toplama aracı olarak araştırmacılar tarafından geliştirilen veri formu ve işe bağlı gerginlik ölçeği kullanıldı.

Bulgular: Çalışmada en fazla katılımcı tarafından belirtilen psikolojik güçlük aile/yakınlara hastalık bulaştırma kaygısı $(\% 93,2)$ iken hizmet sunumunu en fazla güçleştiren etmen kişisel koruyucu ekipman kullanmanın verdiği rahatsızlık (\%85) olarak ifade edildi. COVID-19 salgın döneminde sağlık hizmeti verirken hissedilen kaygı düzeyinin kadınlarda erkeklere göre $(\mathrm{p}=0,01)$ ve hemşirelerde hekimlere göre $(\mathrm{p}=0,001)$ daha fazla olduğu bulundu. Katılımcıların

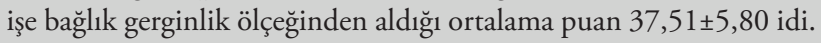

Sonuç: COVID-19 salgın döneminde yakınlar/aileye hastalık bulaştırma endişesi sağlık çalışanları için psikolojik bir güçlük

*This work was supported by Gilead Sciences.

Address for Correspondence: Yasemin GÜNER, Karadeniz Technical University, Faculty of Medical

Received: 11.06 .2020

Science, Department of Medical Education, Trabzon, Turkey

E-mail: yasemin-kul@hotmail.com ORCID ID: orcid.org/0000-0003-4932-771X

Cite this article as: Tatlı Ö, Şimşek P, Güner Y, Kılıç Güner E, Gündüz A. Health Care Professionals' Views on Healthcare Provision During the COVID-19 Pandemic: A Descriptive Study. Bezmialem Science 2021;9(Supplement 1):46-54. 


\section{ABSTRACT}

professionals. Using many personal protective equipments is a factor that makes service delivery difficult. The level of anxiety associated with providing health care is higher in nurses and women during this period.

Keywords: Anxiety, coronavirus disease, health care professionals, health services, pandemic

\section{ÖZ}

oluşturmaktadır. Birçok kişisel koruyucu ekipman kullanmak hizmet sunumunu güçleştiren bir etmendir. Hemşirelerde ve kadınlarda bu dönemde sağlık hizmeti sunma ile ilişkili kaygı düzeyi daha fazladir.

Anahtar Sözcükler: Anksiyete, koronavirüs hastalığı, sağlık profesyonelleri, sağlik hizmetleri, pandemi

\section{"What is already known about the topic?"}

- Healthcare professionals face many challenges providing healthcare during the COVID-19 pandemic.

- Healthcare professionals need accurate, reliable, and up-to-date information to deal with the COVID-19 outbreak.

"What this paper adds".

- Anxiety about infecting families and relatives was the major psychological challenge for healthcare professionals.

- Using personal protective equipment, which is essential for protecting healthcare workers, has made healthcare services difficult.

- Isolation measures were the main topic that healthcare professionals needed information on during the COVID-19 pandemic.

\section{Introduction}

On December 31, 2019, unexplained cases of pneumonia began to appear in Wuhan City, Hubei Province, China. The factor responsible for these cases was determined to be a new Coronavirus disease-19 (COVID-19), which was not previously detected in humans on January 7, 2020. The first case outside China was seen in Thailand on January 13, 2020, and the virus spread rapidly all over the world (1). As of June 28, while the number of confirmed COVID-19 infected cases worldwide was 9.95 million, 498,519 people died due to this infection (2).

Scientific studies are ongoing to prevent the disease spread. Research focuses primarily on disease transmission routes, vaccination, and measures that can be taken. One of the most emphasized measures in this regard is protective behavior (3). It was reported that vulnerability, perceived risk, and fear are among the most important factors in the individuals' engagement with protective behaviors (4). Although social rules and protective behavior can slow disease spread, the pandemic's effect is expected to continue for a long time $(5,6)$.

During the COVID-19 pandemic, healthcare professionals try to fulfill their duties at a high risk of infection. During this period, more than 3,000 healthcare workers in China had a coronavirus infection (7). In Italy, 20\% of healthcare professionals serving in the pandemic period were infected (8). During the COVID-19 pandemic, it was reported that 26\% of COVID-19 cases in Spain (9) and $11 \%$ of cases in the United States (10) were healthcare workers. In a study conducted on an international basis, it was ascertained that 708 healthcare workers lost their lives due to COVID-19 infection until April 27, 2020; 51.5\% were doctors, and $17.7 \%$ were nurses (11).

In addition to the risk of infection, uncertainties caused by the pandemic, stress factors associated with the pandemic, changes in social life, insufficient personal protective equipment, emotional breakdown due to infected co-workers, having to work long hours, and ethical dilemmas posed by the inability to provide the necessary health services to all patients because of insufficient intensive care conditions and the inadequate number of mechanical ventilators were listed among the difficulties faced by healthcare professionals in this process (12,13). All these challenges can negatively affect healthcare professionals psychologically, and this effect may last for a long time. It is determined that the stress and psychological distress experienced by the healthcare professionals continued even one year after the SARS (2002-2004) pandemic, which mainly affected Asian countries (14).

These difficulties may influence the motivation and willingness of healthcare professionals to perform their duties. According to the results of a meta-analysis evaluating the factors affecting the healthcare workers' willingness to work during the influenza outbreak, perceived personal security, pandemic risk awareness, and adequate clinical knowledge, role-specific knowledge, and confidence in personal skills associated with the pandemic were identified as factors that increase willingness to work in this process. The responsibility of childcare has been specified as a factor that lowers the willingness to work during the pandemic disease (15). Low work willingness is also a factor that reduces work efficiency (16). During the pandemic period, healthcare professionals are expected to perform their duties more efficiently.

During pandemics, it is essential to determine the experiences of healthcare professionals and examine their opinions about the difficulties they experienced, to both increase the willingness of the workforce and ensure the safety of employees.

\section{Method}

\section{Design}

The study was designed as a descriptive research study.

\section{Recruitment of the Participants}

The research was conducted at a university hospital in Turkey in a province in the Eastern Black Sea region. The province where 
the research was conducted was among the top 10 provinces with the highest number of deaths and the top 15 provinces with the highest number of cases in the peak period of the COVID-19 pandemic. In addition, the center where the research was performed serves as an education research center and is where patients with special treatment and care needs are referred from neighborhood provinces. Individuals involved in this study consisted of physicians and nurses working at units where patients infected with coronavirus or suspected of infection were followed in the university hospital where the research was conducted. The sampling acceptance criteria determined in the study are as follows: Being over the age of 18, volunteering to participate in the study, being a member of the physician or nursing profession, being responsible for patient care and treatment during the COVID-19 pandemic period, and working actively. The study's exclusion criterion was having less than three months of work experience. The required study sample size to be reached was calculated as 132 , with the sample size formula used in cases where the number of individuals in the population is known in the prediction of the mass ratio.

$\mathrm{n}=\mathrm{N} \mathrm{t}^{2} \mathrm{p} \mathrm{q} / \mathrm{d}^{2}(\mathrm{~N}-1)+\mathrm{t}^{2} \mathrm{p} \mathrm{q}$

$\mathrm{n}=$ Number of individuals to be sampled

$\mathrm{N}=$ Number of individuals in the population (200)

$\mathrm{p}=$ The estimated prevalence of the incident to be investigated in the population $(0.5)$

$\mathrm{q}=1-\mathrm{p}(0.5)$

$\mathrm{t}=$ Theoretical value for the greatest degree of freedom in the $\mathrm{z}$ table at a given confidence level (1.96 for 95\% confidence interval)

$\mathrm{d}=$ Standard error of the rate to be determined in the study $(0.05$ for $95 \%$ confidence interval)

$\mathrm{n}=200 \times 1.962 \times 0.5 \times 0.5 / 0.052 \times 1499+1.962 \times 0.5 \times 0.5=132$

\section{Intervention}

The physicians and nurses in the units where the patients infected with coronavirus or suspected of infection were followed up were invited to participate in the study by giving information about the study. The data collection tool link was then conveyed to the participants through the WhatsApp groups used by physicians and nurses working in these units for communication.

\section{Outcome Measures and Data Collection}

In the study, the job-related strain scale, and the literature form $(12,13)$ were used by the researchers, and the data form created using the Google forms tool was used. The data form consists of seven parts. The first part had seven questions about descriptive characteristics. The second part had two questions regarding healthcare professionals' views on education needs and their information sources about COVID-19. The third part asked two questions regarding the difficulties of healthcare professionals during the management of coronavirus infection cases. The fourth part included one question regarding the technological tools that healthcare professionals needed within the scope of patient care. In the fifth part, one question asked about the level of self-sufficiency in providing health services during the COVID-19 pandemic period. One question was about the level of anxiety related to providing healthcare services. The data form's suitability regarding content was evaluated by four lecturers consisting of physicians and nurses.

Job-related strain scale: The scale was developed by Revicki et al. (17) in 1991. The validity and reliability of the scales conducted by Aslan et al. (18) in Turkey (1998) and the reliability coefficient were between 0.85 and 0.90 , respectively. The Job-Related Strain Scale is a 4-point Likert-type scale with 18 items developed to determine job-related tension and stress in health workers. The items are evaluated as "totally suitable for me," "greatly suitable for me," "partially suitable for me," and "not suitable for me at all." Each item is scored between 4-1 points. Items 2, 4, 8, 9, 11 , and 15 of the scale are graded reversely. The lowest score is 18 , and the highest score is 72 . Studies have shown that the $15^{\text {th }}$ item decreases the item-test correlations of the scale. Therefore, article 15 was removed from the scale $(18,19)$. In this study, the evaluation was made on 17 items, and the Cronbach alpha reliability coefficient was 0.67 .

\section{Statistical Analysis}

Data analysis: SPSS 23 (Statistical Package of Social Sciences) program was used for data analysis. Qualitative data are shown in numbers and percentages (\%) and analyzed by the chisquare test. The suitability of the quantitative data for normal distribution was evaluated with the Kolmogorov-Smirnov test. Parametric tests were used to analyze data that conform to a normal distribution, and non-parametric tests were used to analyze non-compliant data.

Ethical considerations: Ethical approval with the 24237859272 document number was obtained from the Regional Local Ethics Committee for the study. Informed consent was obtained from participants after explaining the aim of the study. Also, an "I was informed about the study, and I agree to participate in the study" button was placed in the first part of the data collection tool. Clicking the button was mandated to answer the questions on the data collection form.

\section{Results}

The overall response rate was $73.5 \%$ in the study. The average age of the healthcare workers who participated in the study was $33.70 \pm 6.8[\operatorname{minimum}(\min )=23$, maximum $(\max )=54]$ years, and $46.9 \%$ were male, and $60.5 \%$ were physicians. The average working time of the participants in their professions was $10.0 \pm 7.0$ $(\min =1, \max =34)$ years. In the study, $4.1 \%$ of participants consisted of healthcare professionals who provided care only to patients diagnosed with COVID-19. While the rate of caregivers for suspicious patients was $43.5 \%$, the rate of caregivers for both suspected and definitive patients was $52.4 \%$ (Table 1 ).

In the study, the psychological difficulties stated by most participants regarding the provision of health services during 
Table 1. Participant characteristics

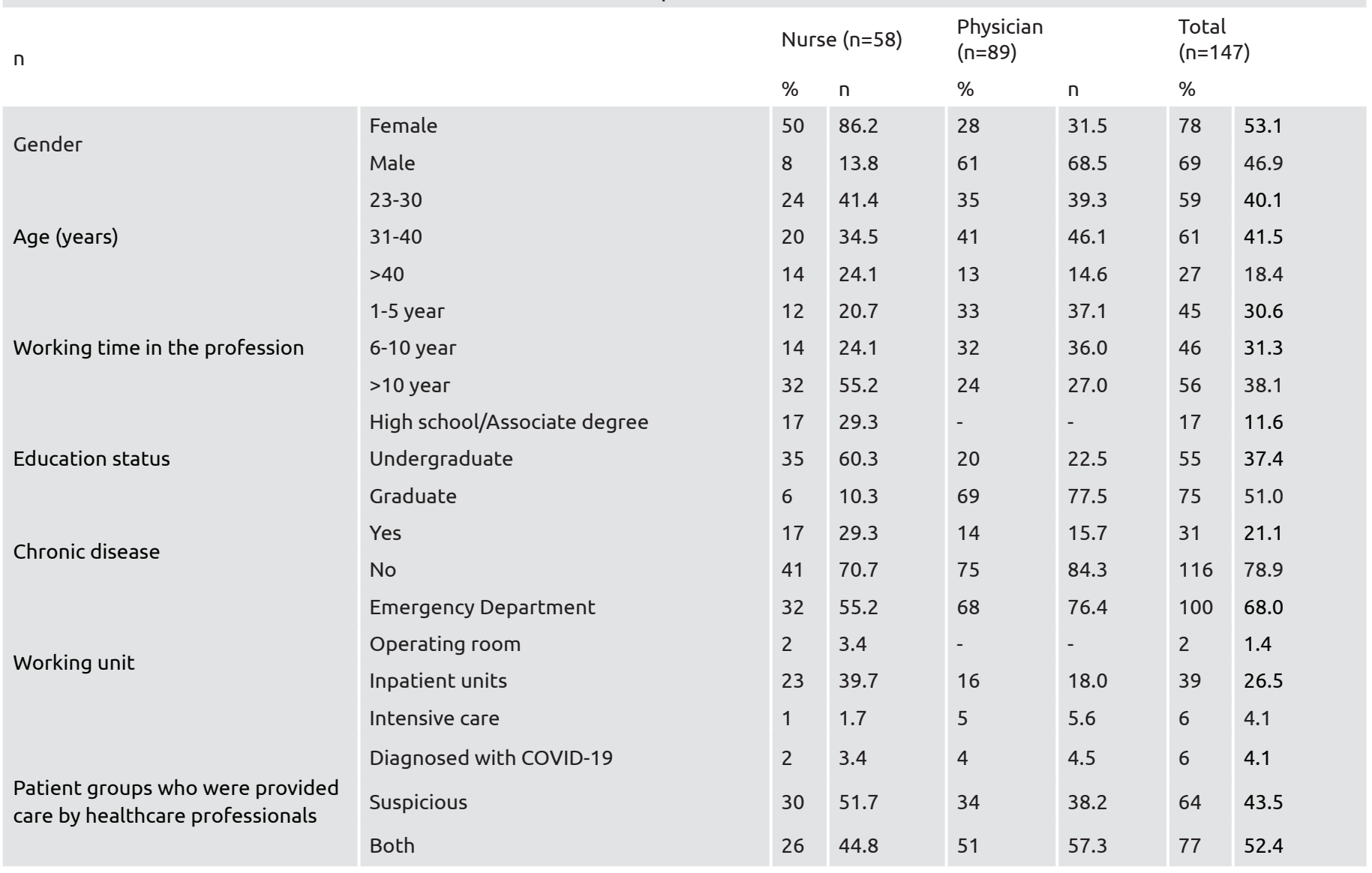

the COVID-19 pandemic were the anxiety (93.2\%) of infecting the family/relatives. In the study, factors that make healthcare provision difficult for healthcare workers were asked. The discomfort caused using personal protective equipment was stated by the highest number of participants $(85.0 \%)$ as a factor that makes it difficult to provide healthcare services. The frequency of staff insufficiency and overtime were considered factors that make healthcare provision difficult was significantly higher in the nurse group than the doctor group $(\mathrm{p}<0.05)$ (Table 2).

During the COVID-19 pandemic, the most needed training subject by healthcare workers was isolation methods $(82.3 \%)$. The second was personal protective equipment $(70.7 \%)$, and the third was the complications that could develop in COVID-19 case management and their prevention methods (69.4\%). While the frequency of expressing that nurses needed training on respiratory system care was higher than physicians, physicians needed training about diagnostic methods was higher $(\mathrm{p}<0.05)$.

Most healthcare professionals used the official website of the Ministry of Health to get information on COVID-19 case management $(87.8 \%)$. When sources of information on COVID-19 case management were analyzed by professional groups, most nurses $(82.8 \%)$ received information from the Ministry of Health official webpage, and $79.3 \%$ of them from in-service training programs. The majority of doctors $(87.8 \%)$ received information from the Ministry of Health official webpage, $66.7 \%$ of doctors from in-service training programs, and $59.9 \%$ of them from academic databases. Nurses had a significantly higher rate of receiving information from inservice training and television programs $(\mathrm{p}<0.05)$. Doctors used academic databases and search engines significantly more than nurses $(\mathrm{p}<0.05)$ (Table 3, 4).

As technological tools to facilitate the provision of health services during the COVID-19 pandemic, 58.5\% of participants stated that sound systems provided a connection with other team members from the isolation room, $48.3 \%$ of them stated their utility as patient follow-up and early warning systems, and $37.4 \%$ of them stated their use as call systems. In the COVID-19 pandemic, there was no significant difference between occupational groups in terms of opinions regarding the technological tools required by healthcare professionals $(p>0.05)$ (Table 4).

In the study, the average score of health workers on the jobrelated strain level was calculated as $37.51 \pm 5.80 \quad(\min =18$, $\max =53$ ). When the scale scores were examined according to the variables of the profession, age groups, gender, education level, and duration in the profession, there was no statistically significant difference between the groups ( $p>0.05)$ (Table 5).

In the study, $25.9 \%$ of healthcare professionals who participated stated that they considered themselves completely sufficient while providing care to patients who were followed up with suspicion 
Table 2. Healthcare professionals' difficulties during the COVID-19 pandemic period ( $n=147$ )

\begin{tabular}{|c|c|c|c|c|}
\hline & $\begin{array}{l}\text { Nurse } \\
\text { n (\%) }\end{array}$ & $\begin{array}{l}\text { Physician } \\
\text { n (\%) }\end{array}$ & $\begin{array}{l}\text { Total } \\
\text { n (\%) }\end{array}$ & $\mathrm{p}$ \\
\hline \multicolumn{5}{|l|}{ Psychological difficulties } \\
\hline Anxiety about getting infected & $46(79.3)$ & $60(67.4)$ & $106(72.1)$ & 0.166 \\
\hline Unable to provide quality communication with patients & $25(43.1)$ & $48(53.9)$ & $73(49.7)$ & 0.199 \\
\hline Worries about death & $20(34.5)$ & $13(14.6)$ & $33(22.4)$ & 0.009 \\
\hline Sense of inadequacy in intervention & $14(24.1)$ & $17(19.1)$ & $31(21.1)$ & 0.600 \\
\hline \multicolumn{5}{|l|}{ Factors that make healthcare delivery difficult } \\
\hline PPE use discomfort & $52(89.7)$ & $73(82.0)$ & $125(85.0)$ & 0.302 \\
\hline Mandatory quarantine, unable to go home & $8(13.8)$ & $14(15.7)$ & $22(15.0)$ & 0.932 \\
\hline Overtime & $17(29.3)$ & $12(13.5)$ & $29(19.7)$ & 0.032 \\
\hline
\end{tabular}

Table 3. Healthcare professionals' views on educational needs and their information sources about COVID-19

\begin{tabular}{|c|c|c|c|c|}
\hline & $\begin{array}{l}\text { Nurse } \\
(n=58)\end{array}$ & $\begin{array}{l}\text { Physician } \\
(n=89)\end{array}$ & $\begin{array}{l}\text { Total } \\
(n=147)\end{array}$ & $p$ \\
\hline & n (\%) & n (\%) & n (\%) & \\
\hline \multicolumn{5}{|l|}{ Educational subjects } \\
\hline Insulation measures & $48(82.8)$ & $73(82.0)$ & $121(82.3)$ & 1.000 \\
\hline Use of PPE* & $41(70.7)$ & $63(70.8)$ & $104(70.7)$ & 1.000 \\
\hline Preventing complications & $41(70.7)$ & $61(68.5)$ & $102(69.4)$ & 0.926 \\
\hline Respiratory care & $46(79.3)$ & $52(58.4)$ & $98(66.7)$ & 0.014 \\
\hline Medical treatments & $31(53.4)$ & $49(55.1)$ & $80(54.4)$ & 0.848 \\
\hline Diagnostic methods & $17(29.3)$ & $49(55.1)$ & $66(44.9)$ & 0.002 \\
\hline \multicolumn{5}{|l|}{ Sources of information } \\
\hline Official ministry website & $48(82.8)$ & $81(91.0)$ & $129(87.8)$ & 0.217 \\
\hline In-house training & $46(79.3)$ & $52(58.4)$ & $98(66.7)$ & 0.014 \\
\hline Academic databases & $21(36.2)$ & $67(75.3)$ & $88(59.9)$ & 0.000 \\
\hline Social sharing sites & $26(44.8)$ & $32(36.0)$ & $58(39.5)$ & 0.366 \\
\hline Internet search engines & $14(24.1)$ & $37(41.6)$ & $51(34.7)$ & 0.046 \\
\hline Television programs & $24(41.4)$ & $10(11.2)$ & $34(23.1)$ & 0.000 \\
\hline Newspapers & $8(13.8)$ & $8(9.0)$ & $16(10.9)$ & 0.520 \\
\hline
\end{tabular}

of COVID-19 or who had a definitive diagnosis. While $70.1 \%$ of participants found themselves partially sufficient in this regard, $4.1 \%(n=6)$ stated that they did not consider themselves sufficient. During the COVID-19 pandemic, no significant difference was found regarding the self-sufficient qualifications of healthcare professionals while performing their duties $(\mathrm{p}>0.05)$.

The healthcare workers who participated in the study were asked if providing healthcare during the COVID-19 pandemic caused anxiety. While $2.0 \%$ of health workers stated that they did not experience anxiety, 33.3\% ( $\mathrm{n}=49)$ rated their level of anxiety due to providing health services in this period as "very" and 64.6\% as "partially". When the level of anxiety caused by performing health services during the COVID-19 pandemic was analyzed according to healthcare professionals' descriptive characteristics, the average rank of women (81.13) was significantly higher than that of men (65.94) $(U=2135.0, p=0.01)$. When the professions were compared, the average level of anxiety level of nurses 
Table 4. Technological tools required by healthcare workers during the COVID-19 pandemic $(n=147)$

\begin{tabular}{|c|c|c|c|c|}
\hline & $\begin{array}{l}\text { Nurse } \\
\mathrm{n}(\%)\end{array}$ & $\begin{array}{l}\text { Physician } \\
\mathrm{n}(\%)\end{array}$ & $\begin{array}{l}\text { Total } \\
\text { n (\%) }\end{array}$ & $p$ \\
\hline $\begin{array}{l}\text { Sound systems to connect with other team members from the isolation } \\
\text { room }\end{array}$ & $35(60.3)$ & $51(57.3)$ & $86(58.5)$ & 0.846 \\
\hline Patient monitoring and early warning systems & $33(56.9)$ & $38(42.7)$ & $71(48.3)$ & 0.092 \\
\hline Hospital paging system & $24(41.4)$ & $31(34.8)$ & $55(37.4)$ & 0.530 \\
\hline Mobile applications & $21(36.2)$ & $30(33.7)$ & $51(34.7)$ & 0.894 \\
\hline $\begin{array}{l}\text { Telehealth applications for communication with healthcare professionals } \\
\text { at other institutions }\end{array}$ & $21(36.2)$ & $22(24.7)$ & $43(29.3)$ & 0.190 \\
\hline Decision support systems & $13(22.4)$ & $27(30.3)$ & $40(27.2)$ & 0.387 \\
\hline Emergency button & $14(24.1)$ & $19(21.3)$ & $33(22.4)$ & 0.846 \\
\hline
\end{tabular}

Table 5. Distribution of Job-Related Strain scale scores by descriptive characteristics

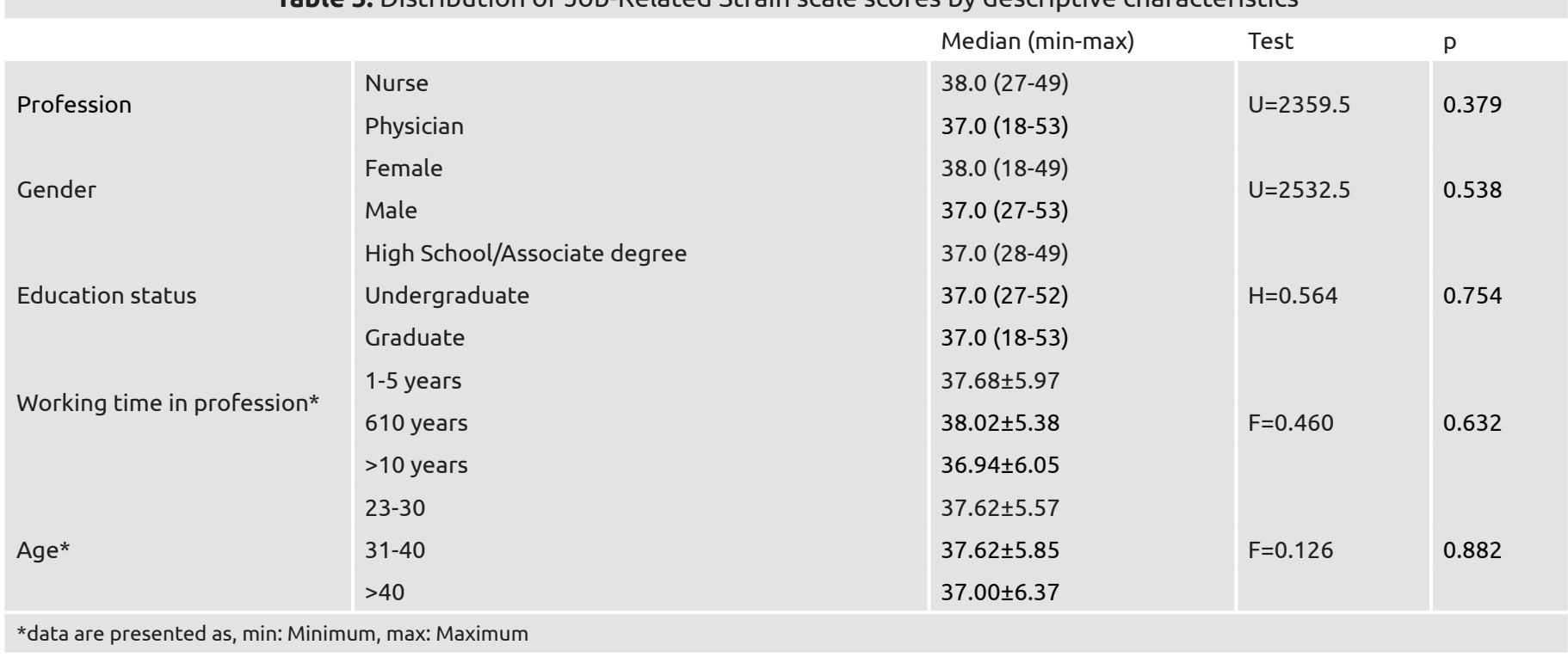

$(85,76)$ was higher than doctors (66.34) $(\mathrm{U}=1899.0, \mathrm{p}=0.001)$. When the anxiety level caused by providing healthcare services in the COVID-19 pandemic period was examined according to other introductory features, there was no statistically significant difference $(\mathrm{p}>0.05)$.

\section{Discussion}

As a consequence of its high virulence and genetic properties, COVID-19 has spread rapidly. The rapid expansion has turned into a pandemic that will shake the economic structure, social life, and health system of countries worldwide. In this process, various difficulties have arisen for all layers of society. Health workers, who are responsible for fighting the pandemic and maintaining health services, are among the most affected individuals in this process (12).

The study ascertained that the psychological difficulties healthcare professionals experienced the most during the COVID-19 pandemic were concerns about infecting their family/relatives and anxiety about getting infected. Similarly, in the SARS pandemic, healthcare workers expressed their fear and anxiety about infecting their families, friends, and colleagues (19). During the pandemic of COVID-19, 3387 healthcare workers were infected in Hubei Province in China until February 25, 2020, which caused increased concern among healthcare workers (20). In addition, COVID-19 infection is not only transmitted through symptomatic individuals, but asymptomatic individuals can become infectious and viral transmission from healthcare professionals to family members is common $(11,21)$. During the COVID-19 pandemic, to prevent their family members from getting infected, healthcare professionals were not allowed to go home, and they were provided different accommodation services $(22,23)$. Nevertheless, the study results emphasize the importance of early detection of psychological problems faced by healthcare workers during pandemics and the need to establish adequate support systems and develop solutions. 
In the current study, in the process of the COVID-19 pandemic, most participants stated that the discomfort caused by the use of personal protective equipment made healthcare provision difficult. The use of personal protective equipment during the pandemic is vital to protect healthcare workers against the virus. It has been established that none of the healthcare professionals who performed the procedures that cause exposure to respiratory tract secretions of COVID-19 patients by using personal protective equipment were infected (24). However, various studies showed that the use of this equipment could lead to various problems. In the study of Oranges et al., due to personal protective equipment, skin problems in the nose and cheeks have generally been reported. In addition, symptoms such as burning, itching, or stinging could be observed due to the long stay of the masks on faces. This can lead healthcare professionals to perform behaviors that facilitate the spread of infection, such as adjusting and touching the equipment (25). Personal protective equipment can also cause dehydration, sweating, and fatigue; wearing personal protective equipment for a long time while working may cause isolation, claustrophobia, and anxiety (26). Healthcare workers' working hours can be shortened by providing personnel support to prevent these problems. In addition, by developing technological opportunities, producing personal protective equipment that healthcare professionals can use more easily is considered necessary.

Approximately half of the participants stated that staff shortage and overtime made healthcare provision difficult. The insufficient number of health professionals is a common problem for the whole world (27). However, healthcare workers being quarantined because they got infected or their family members were infected during the pandemic of COVID-19 further increased the need for healthcare workers $(28,29)$. Especially at the beginning of the pandemic, unknown infectious factors, insufficient personal protective equipment, and the low level of awareness about the use of this equipment increased the risk in the role played by healthcare professionals. As a result, healthcare workers' workload and working time increased (20). It was also found that the frequency of staff shortage and overtime considered as factors that make healthcare provision difficult was higher in the nurse group than the physician group in the study. This may be related to the fact that nurses communicate more with patients than other healthcare professionals and are directly involved in the diagnosis, treatment, and care of patients. In addition, it is believed that since women constitute the majority of nurses, and overtime can cause women to experience anxiety of not being able to fulfill their domestic and social responsibilities. In addition, the anxiety in question may be higher in the nurse group than in the male gender-based physician group.

It was founded that most health professionals needed training on isolation measures. Because of the insufficient number of personnel employed in intensive care and infection services during pandemics, healthcare professionals working in different units can be assigned to these units (30). However, the extremely rapid progress of the process can make it difficult for healthcare professionals to devote enough time to training on the management of infected cases and new tasks. As a result, healthcare professionals may feel the need for training on various topics related to infected case management. In the study, the other topics that healthcare professionals needed training the most were the use of personal protective equipment, and complications that could occur in COVID-19 case management, and ways to prevent them. It is essential to organize the necessary training activities for healthcare professionals, prevent the spread of the infection in the hospital environment, and maintain the best patient care.

The official website of the Ministry of Health was the source of information that was used by healthcare professionals most frequently for gathering information on COVID-19 case management. In a study conducted during the $\mathrm{H} 1 \mathrm{~N} 1$ outbreak period, healthcare professionals often obtained the information they needed via radio and television. The rate of benefiting from the internet and medical journals was low (31). In our study, physicians used academic databases and search engines, and nurses used television programs to obtain information during the COVID-19 pandemic. Similar to our findings, it was found that nurses consulted specialists and colleagues rather than using the internet for professional information (32), whereas physicians preferred internet resources to obtain professional knowledge (33). Considering the resources preferred by healthcare professionals to obtain the information they need is important regarding reaching the target of personnel training activities during pandemics. In addition, distance in-service training programs may be useful for training and awarenessraising activities.

We found that that approximately half of the participants thought that various telemedicine applications, patient follow-up, and early warning systems could facilitate healthcare delivery during the COVID-19 pandemic. Due to its highly contagious nature, COVID-19 infection necessitated working under strict isolation measures. This situation can make communication between healthcare workers difficult and may cause disruptions in the bedside consultation process. In addition, the very rapid spread of COVID-19 infection has revealed the need to obtain accurate information about case management for healthcare professionals very quickly and to receive support from technological tools to meet the rapid increase in the need for treatment and care. Telemedicine is considered a groundbreaking technology that can provide online conversation and real-time clinical data exchange to tackle these challenges caused by the pandemic and combat outbreaks. Telemedicine was used for remote patient follow-up, multidisciplinary care organizations, and educational purposes in this period (34).

In our study, it was ascertained that healthcare workers received moderate scores from the job-related strain scale. The uncertainties brought about by the pandemic process can be a source of anxiety and tension. In addition, facing the infectious agent directly, trying to meet the complex care needs of patients both physiologically and psychologically, and managing to continue their treatment are factors that may affect healthcare workers' 
job-related strain $(35,36)$. The studies conducted determined that healthcare professionals experienced psychological distress during the COVID-19 pandemic and showed symptoms of anxiety, depression (37), and insomnia (38).

In the current study, nurses experienced more anxiety than physicians and women more than men while caring for COVID19-infected or suspicious patients. Similar to our study, the anxiety level of nurses in the severe acute respiratory syndrome (2002-2004) outbreak was higher than in physicians (39). Nurses who continue to provide treatment and care services of COVID-19 patients are exposed to a high risk of infection because of their close, frequent contact with patients and prolonged time working during the pandemic. These stressful working conditions can result in anxiety and post-traumatic stress disorder $(37,38)$.

\section{Study Limitations}

The study was carried out at a single center. This caused study limitations. Because of social distance rules and the outbreak situation, the study was not conducted face to face. This is another limitation of the study.

\section{Conclusion}

In the COVID-19 pandemic period, using personal protective equipment was a factor that made it difficult for healthcare workers to work. In contrast, anxiety about transmitting the disease to others was a major concern for healthcare workers. During the COVID-19 pandemic, health workers mostly used the official website of the Ministry of Health for information. According to healthcare professionals, various telemedicine applications are technological tools that can facilitate service delivery in this process.

\section{Ethics}

Ethics Committee Approval: Ethical approval with the 24237859-272 document number was obtained from the Regional Local Ethics Committee for the study.

Informed Consent: Informed consent was obtained from participants after explaining the aim of the study. Also, an "I was informed about the study, and I agree to participate in the study" button was placed in the first part of the data collection tool. Clicking the button was mandated to answer the questions on the data collection form.

Peer-review: Externally peer reviewed.

\section{Authorship Contributions}

Concept: Ö.T., P.Ş., Y.G., E.K.G., A.G., Design: Ö.T., P.Ş., Y.G., E.K.G., A.G., Data Collection or Processing: Ö.T., P.Ş., Y.G., E.K.G., E.K.G., Analysis or Interpretation: Ö.T., P.Ş., Y.G., Literature Search: Ö.T., P.Ş., Y.G., Writing: Ö.T., P.Ş., Y.G., E.K.G., E.K.G.

Conflict of Interest: No conflict of interest was declared by the authors.
Financial Disclosure: This work was supported by Gilead Sciences.

\section{References}

1. World Health Organization. Archived: WHOTimeline - COVID-19. Last Accessed Date: 28.06.2020. Available from: https://www.who. $\mathrm{int} /$ news-room/detail/27-04-2020-who-timeline---covid-19.

2. Our world in Data. Statistics and Research - Coronavirus Pandemic (COVID-19). Last Accessed Date: 28.06.2020 Available from: https://ourworldindata.org/coronavirus.

3. Xu ZQ, Wang JZ, Wang HR, He JF, Wang B, Yang YC. et al. Research on COVID-19 prevention and control strategies, and the effect of home quarantine in Shenzhen, China, 2020. Preventive Medicine 2020 Apr 29. doi:10.21203/rs.3.rs-23969/v1. [Epub ahead of print]

4. Yıldırım M, Geçer E, Akgül Ö. The impacts of vulnerability, perceived risk, and fear on preventive behaviours against COVID-19. Psychol Health Med 2021;26:35-43.

5. Katie Pearce. John Hopkins University. What is social distancing and how can it slow the spread of COVID-19? Last Accessed Date: 28.06.2020. Available from: https://hub.jhu.edu/2020/03/13/whatis-social-distancing.

6. Açikgöz Ö, Günay A. The early impact of the Covid-19 pandemic on the global and Turkish economy. Turk J Med Sci 2020;50:520-526.

7. Kaltwasser J. Coronavirus: For health care workers, risk of infection, but also burnout. Last Accessed Date: 27.03.2020 Available from: https://www.contagionlive.com/news/for-health-care-workers-riskof-infection-but-also-burnout. The Lancet. COVID-19: Protecting health-care workers. Lancet 2020;395:922.

8. Ministerio de Sanidad Espana. Informe sobre la situación de COVID-19 en Espańa. Informe COVID-19 no 20. 3 de abril 2020. Last Accessed Date: 25.06.2020. Available from: https://www. isciii.es/QueHacemos/Servicios/VigilanciaSaludPublicaRENAVE/ EnfermedadesTransmisibles/Paginas/InformesCOVID-19.aspx.

9. Jewett C, Szabo L. True Toll Of COVID-19 on U.S. health care workers unknown. Keiser Health News. Last Accessed Date: 25.06.2020. Available from: https://khn.org/news/true-toll-ofCOVID-19-on-u-s-health-care-workers-unknown.

10. Beyazadam D, Alimoğlu O. Healthcare Workers Are Losing Their Lives in the Battle of COVID-19 All Over the Globe. Anadolu Clinic Journal of Medical Sciences 2020;25:183-4.

11. Shmerling HR. What's it like to be a healthcare worker in a pandemic? Last Accessed Date: 27.04.2020. Available from: https://www.health. harvard.edu/blog/whats-it-like-to-be-a-healthcare-worker-in-apandemic-2020040819485.

12. Choudhury T, Debski M, Wiper A, Abdelrahman A, Wild S, Chalil $S$, et al. COVID-19 Pandemic: Looking after the mental health of uur healthcare workers. J Occup Environ Med 2020;62:373-6.

13. Lee AM, Wong JG, McAlonan GM, Cheung V, Cheung C, Sham PC, et al. Stress and psychological distress among SARS survivors 1 year after the outbreak. Can J Psychiatry 2007;52:233-40.

14. Aoyagi Y, Beck CR, Dingwall R, Nguyen-Van-Tam JS. Healthcare workers' willingness to work during an influenza pandemic: a 
systematic review and meta-analysis. Influenza Other Respir Viruses 2015;9:120-30.

15. Manninen O. Willingness and ability to keep on working: Care work and care working communities compared with 10,000 other tasks and working communities. Work Among the Elderly, Edition: Book, Publisher: Work Life Ability Networks, Tampere Adult Educational Centre, And The ISCES Society; Finland: Printing Company Kopijyvä Oy Ltd, Tampere; 2011.p.9-31.

16. Revicki DA, May HJ, Whitley TW. Reliability and validity of the work related strain inventory among health professionals. Behavioral Medicine 1991; 17:20.

17. Aslan SH, Alparslan ZN, Aslan RO, Kesepara C, Ünal M (1998). Validity and reliability of job-related strain scale in healthcare workers. Dusunen Adam The Journal of Psychiatry and Neurological Science 1998;11::4-8.

18. Aslan H, Coşkun S, Alpaslan N. Bakırköy ruh ve sinir hastalıkları hastanesi'nde çalışan hemşirelerde tükenme, işe bağlı gerginlik, A-tipi kişilik ve mükemmeliyetçilik. Cumhuriyet Üniversitesi Tıp Fakültesi Dergisi 2020;25:135-141.

19. Maunder R, Hunter J, Vincent L, Bennett J, Peladeau N, Leszcz M, et al. The immediate psychological and occupational impact of the 2003 SARS outbreak in a teaching hospital. CMAJ 2003;168:124551.

20. Su A. Doctors and nurses fighting coronavirus in China die of both infection and fatigue. Los Angeles Times Feb, 25. Last Accessed Date: 25.06.2020. Available from: https://www.latimes.com/world-nation/ story/2020-02-25/doctors-fighting-coronavirus-in-china-die-ofboth-infection-and-fatigue.

21. Bai Y, Yao L, Wei T, Tian F, Jin DY, Chen L, et al. Presumed asymptomatic carrier transmission of COVID-19. JAMA 2020;323:1406-7.

22. Hu Z, Song C, Xu C, Jin G, Chen Y, Xu X, et al. Clinical characteristics of 24 asymptomatic infections with COVID-19 screened among close contacts in Nanjing, China. Sci China Life Sci 2020;63:706-11.

23. Adams JG, Walls RM. Supporting the health care workforce during the COVID-19 global epidemic. JAMA 2020;323:1439-40.

24. Ng K, Poon BH, Kiat Puar TH, Shan Quah JL, Loh WJ, Wong YJ, et al. COVID-19 and the risk to health care workers: A case report. Ann Intern Med 2020;172:766-7.

25. Oranges T, Janowska A, Dini V. Reply to: Skin damage among health care workers managing coronavirus disease-2019. J Am Acad Dermatol 2020;82:233-4.

26. Center for the study of traumatic stress. Prolonged operations in personal protective equipment during COVID-19: Recommendations for workers and managers. Last Accessed Date: 20.06.2020. Available from: https://www.cstsonline.org/assets/media/documents/CSTS FS_Prolonged_Operations_in_Personal_Protective_Equipment.pdf.

27. WHO. Health Workforce. Last Accessed Date: 20.06.2020. Available from: https://www.who.int/health-topics/healthworkforce\#tab=tab_1.
28. Public Health England (PHE) COVID-19: Guidance for healthcare providers who have diagnosed a case within their facility. London: PHE. Last Accessed Date: 22.03.2020. Available from: https:// www.gov.uk/government/publications/COVID-19-guidance-forhealthcare-providers-who-have-diagnosed-a-case-within-their-facility

29. Keeley AJ, Evans C, Colton H, Ankcorn M, Cope A, State A, et al. Roll-out of SARS-CoV-2 testing for healthcare workers at a large NHS foundation trust in the United Kingdom, March 2020. Euro Surveill 2020;25:2000433.

30. Information and advice on occupational risks to healthcare professionals during the COVID-19 outbreak. Turkish Thoracic Society. Last Accessed Date: 20.06.2020. Available from: https:// www.toraks.org.tr/halk/news.aspx?detail=5768.

31. Etokidem A, Ogaji D, Nsan E, Ikpeme BM, Oyo-Ita AE, Ndifon WO, et al. Influenza A H1N1 (Pandemic 2009): How prepared are healthcare providers in Calabar, Nigeria? J Infect Dis Immun 2012;4:23-28.

32. Marshall AP, West SH, Aitken LM. Preferred information sources for clinical decision making: Critical care nurses' perceptions of information accessibility and usefulness. Worldviews Evid Based Nurs 2011;8:224-35.

33. Podichetty VK, Booher J, Whitfield M, Biscup RS. Assessment of internet use and effects among healthcare professionals: A cross sectional survey. Postgrad Med J 2006;82:274-9.

34. Zhai Y, Wang Y, Zhang M, Gittell JH, Jiang S, Chen B, et al. From Isolation to Coordination : How Can Telemedicine Help Combat the COVID - 19 Outbreak? medRxiv 2020 Feb 23. doi.10.1101/2020.0 2.20.20025957. [Epub ahead of print]

35. Ocak HN. The Psychological Effects of the Pandemic Process Spreads As Fast As The Virus. Last Accessed Date: 20.06.2020. Available from: https://www.istanbul.edu.tr/tr/haber/pandemi-surecininpsikolojik-etkileri-virus-kadar-hizla-yayiliyor4B006900540051006B 0032004600690073004300720039007900700046006200610041 004F003200370077003200.

36. Schwartz J, King CC, Yen MY. Protecting healthcare workers during the coronavirus disease 2019 (COVID-19) Outbreak: Lessons from Taiwan's severe acute respiratory syndrome response. Clin Infect Dis 2020;71:858-60.

37. Lai J, Ma S, Wang Y, Cai Z, Hu J, Wei N, et al. Factors associated with mental health outcomes among health care workers exposed to coronavirus disease 2019. JAMA Netw Open 2020;3:203976.

38. Turkish Psychiatric Association. A guide to coping with fear and anxiety for COVID-19 for physicians and healthcare professionals. Last Accessed Date: 22.06.2020. Available from: https://www. psikiyatri.org.tr/uploadFiles/213202011418-saglikcalisanibrosur. pdf.

39. Wong TW, Yau JK, Chan CL, Kwong RS, Ho SM, Lau CC, et al. The psychological impact of severe acute respiratory syndrome outbreak on healthcare workers in emergency departments and how they cope. Eur J Emerg Med 2005;12:13-8. 